\title{
Daerah penangkapan pukat cincin untuk ikan cakalang yang didaratkan di Pelabuhan Perikanan Samudera Bitung
}

\author{
Fishing ground of purse seine for skipjack landed at Bitung Oceanic Fishing Port \\ WAWAN SUTIYO*, IVOR L. LABARO dan ALFRET LUASUANAUNG \\ Program Studi Pemanfaatan Sumberdaya Perikanan, Fakultas Perikanan dan Ilmu Kelautan \\ Universitas Sam Ratulangi, 95115
}

\begin{abstract}
The information of fishing ground of tuna landed at the Oceanic Fishing Port (OFP) of Bitung is not widely known. Manu people thought that the landed skipjack are from the sea of Sulawesi and the Moluccas. Therefore, a research has been done to assess the position of the fishing area and the catch volume of tuna in purse seine fishery at Bitung OFP. Monthly fishing effort in the period of Februari to May reaches a peak in March with the amount of effort was 130 ships in March and 124 ships in May. The index of fishing season indicated that the season of skipjack fishing in the eastern Indonesian waters occurred in May and October to December with the peak was in November. The trend of monthly catches showed that the lowest catches of 5485.88 tons/year in July and the highest of 11882.37 tons/year in November. The position of purse seine fishing grounds that have high intensity were in Sulawesi waters and in the Gulf of Cendrawasih. Mapping of fishing ground of skipjack landed at the PPS Bitung are of the Moluccas Sea, Pacific Ocean, the Seram Sea, Raja Ampat Islands waters, Halmahera Sea and Celebes Sea. Halmahera Sea and the Moluccas Sea are the most productive fishing area.
\end{abstract}

Keywords: skipjack, fishing ground, fishing season, purse seine, Bitung

\begin{abstract}
ABSTRAK
Informasi posisi daerah penangkapan ikan cakalang yang didaratkan di Pelabuhan Perikanan Samudera (PPS) Bitung belum banyak diketahui. Banyak orang beranggapan bahwa cakalang yang didaratkan tersebut adalah hasil tangkapan dari Laut Sulawesi dan Maluku. Oleh karena itu dilakukan penelitian tentang posisi daerah penangkapan dan hasil tangkapan ikan cakalang pada alat tangkap pukat cincin yang didaratkan di PPS Bitung; dan memetakan daerah penangkapan tersebut. Upaya tangkap bulanan berpuncak pada bulan Maret dalam rentang waktu Februari hingga Mei dengan jumlah upaya sebanyak 130 kapal pada bulan Maret dan sebanyak 124 kapal pada bulan Mei. Berdasarkan index musim, musim tangkapan ikan cakalang di perairan timur Indonesia terjadi pada bulan Mei dan Oktober hingga Desember dengan puncak musim pada bulan November. Tren tangkapan bulanan menunjukkan hasil tangkapan terendah 5.485,88 ton/tahun pada bulan Juli dan tertinggi $11.882,37$ ton/tahun pada bulan November. Posisi daerah penangkapan pukat cincin dengan intensitas penangkapan tertinggi berada di wilayah Sulawesi dan Teluk Cendrawasih. Pemetaan daerah penangkapan cakalang yang didaratkan di PPS Bitung yaitu dari Laut Maluku, Samudera Pasifik, Laut Seram, Laut Kepulauan Raja Ampat, Laut Halmahera dan Laut Sulawesi dengan Laut Halmahera dan Laut Maluku sebagai daerah penangkapan yang produktif.
\end{abstract}

Kata-kata kunci: cakalang, daerah penangkapan, musim penangkapan, pukat cincin, Bitung

\section{PENDAHULUAN}

Potensi kelautan dan perikanan Indonesia begitu besar. Berbagai kebijakan program dan kegiatan pembangunan sektor kelautan dan perikanan telah dilaksanakan dan dirasakan manfaatnya. Namun

\footnotetext{
* Penulis untuk penyuratan; email: wawan_sutiyo@yahoo.com
}

sejalan dengan perubahan yang begitu cepat di segala bidang, baik secara internasional maupun nasional, maka kebijakan, program dan kegiatan pembangunan sektor kelautan dan perikanan memerlukan penyesuaian atau perubahan agar dapat memenuhi kebutuhan ekonomi yang lebih fokus pada peningkatan kesejahteraan rakyat. Dalam rangka memenuhi harapan tersebut, 